\title{
EVALUATION FOR NEPHROPROTECTIVE ACTIVITY OF ETHANOLIC EXTRACT OF ALLIUM CEPA LINN. IN GENTAMICIN-INDUCED NEPHROTOXICITY IN RATS
}

\author{
KRISHNA MOHAN CHINNALA*, PRATHYUSHA ACHANTA, VIJAYA LAXMI VANGALA, MADHAN MOHAN ELSANI
}

Department of Pharmacology, School of Pharmacy, Nalla Narasimha Reddy Education Society's Group of Institutions, Hyderabad - 500 088, Telangana, India. Email: drchinnala@gmail.com

Received: 21 November 2016, Revised and Accepted: 19 December 2016

\section{ABSTRACT}

Objective: Kidney diseases are a major problem of worldwide proportions, and renal damage is very common since kidney has the capacity to excrete toxic substances. This study aimed to evaluate the protective effect of the ethanolic extract of Allium cepa Linn. (EEAC) plant leaves against gentamicininduced nephrotoxicity in rats.

Methods: Nephroprotective activity was estimated by inducing gentamicin $(100 \mathrm{mg} / \mathrm{kg})$ to all the groups of animals; acute kidney dysfunction is an evidenced by significant elevation of serum creatinine, total protein and decreased body weight with multiple histological damages.

Results: Treatment with the $A$. cepa Linn. has shown significant $(\mathrm{p}<0.01$ and $\mathrm{p}<0.001)$ dose-dependent improvement in the body weight at the dose of 200 and $400 \mathrm{mg} / \mathrm{kg}$ and also shown significant improvement by protecting the kidney from the oxidative stress. It is also identified that treatment with $A$. cepa significantly lowered the level of serum creatinine, total protein when compared with the toxic group.

Conclusion: Nephroprotective activity of EEAC treatment was found compared with the standard group (Vitamin E - 250 mg/kg) and control group against the toxic control group animals in parameters including serum creatinine, total protein, kidney weights, and body weights. The histopathological studies were also evinced the protective effect of EEAC.

Keywords: Nephroprotective activity, Gentamicin, Nephrotoxicity, Allium cepa Linn.

(C) 2017 The Authors. Published by Innovare Academic Sciences Pvt Ltd. This is an open access article under the CC BY license (http://creativecommons. org/licenses/by/4. 0/) DOI: http://dx.doi.org/10.22159/ajpcr.2017.v10i3.16271

\section{INTRODUCTION}

Nephrotoxicity is the most common kidney problem, occurs when the body is exposed to a drug or toxin [1]. Nephrotoxicity is manifested functionally by decreased urine concentrating capacity, tubular proteinuria, lysosomal enzymuria and mid glucosuria, decreased ammonium excretion lowering of glomerular filtration rate, creatinine clearance and increase in serum blood urea nitrogen, and serum creatinine level with kidney tissue morphological alteration. A number of therapeutic agents, chemicals, and heavy metals can adversely affect the kidney resulting in acute renal failure, chronic intestinal nephritis and nephritic syndrome which may lead to permanent renal damage [2]. On the other hand, the improper renal function also directly influence cardiovascular function. Gentamicin is an aminoglyciside antibiotic used for severe infections classically, the nephrotoxicity of gentamicin has been considered as a tubulopathy in which tubular damage and tubular dysfunction are the main cause of renal insufficiency. This may explain some clinical observations such as proteinuria, enzymuria, and electrolytic alterations [3].

Allium cepa Linn. belongs to the family Alliaceae have spread many parts of the world with widely differing climates and contains major chemical constituents such as quercetin, quercetin-3-glucoside, isorhamnetin-4-glucoside, xylose, galactose, glucose, mannose, organosulfur compounds, allyl sulfides, flavonoids, flavenols, cyclically, selenium, thiosulfinates, and sulfur and seleno compounds [4]. Allium vegetables health properties have been supported by numerous in vitro, in vivo, and ex vivo studies. Particularly, A. cepa has been described to have several health benefits related to its antioxidant, anticarcinogenic, hypolipidemic, and hypoglycemic effects. From a medical and nutritionally point of view, it has to be taken into account that the A. cepa used as a food or a food ingredient in the elaboration of many dishes also exerts a wide variety of medicinal effects, which are very interesting for its human health potential benefits. Traditionally, A. cepa used as an antimicrobial, cardiovascular supportive, hypoglycemic, antioxidant/anticancer, and asthma protective agent. A. сера also reported for its several pharmacological activities such as antioxidant [5], cardioprotective [6], neuroprotective [7], anticonvulsant activity [8], and antidiabetic effects [9]. However, no work is reported regarding the nephroprotective effect of $A$. сера. Therefore, this study was designed to evaluate the nephroprotective effect of aqueous extract of $A$. сера on gentamicin-induced nephrotoxicity in rats.

\section{METHODS}

Collection and authentication of plant material

Leaves of A. cepa (onion) were collected from the local area of Hyderabad (India) in the month of January and authenticated by Ms. D. Kavitha, Assistant Professor, Department of Botany, Osmania University, Hyderabad, India.

Preparation of ethanolic extract of $A$. cepa (EEAC)

The leaves of $A$. сера (onion) were cleaned and removed adherent sand and dust particles. It was dried and made into a coarse powder with the help of electric grinder. About $1000 \mathrm{~g}$ of grinded plant material was subject to extraction $\left(60-70^{\circ}\right)$ employing ethanol $(95 \%)$ as solvent [10]. The solvent was evaporated at room temperature to obtain a viscous mass. It was filtered, and the solvent was removed. The dried molten mass was brown in color and was stored in dessicator until use. The extract was suspended in distilled water using sodium carboxymethyl cellulose as suspending agent for oral administration to animals.

Experimental animals

Sprague Dawley rats (150-200 g) of male sex were procured from Sainath Agencies, (CPCSEA Reg. No: 282/99/CPCSEA) Hyderabad, 
Telangana. Animals were housed at CPCSEA approved Animal House of School of Pharmacy, Nalla Narasimha Reddy Education Society's Group of Institutions, Hyderabad. The animals were kept in polypropylene cages ( 6 in each cage) under standard laboratory conditions (12 hrs light and 12 hrs dark cycle) and had free access to commercial pellet diet (Hindustan Lever Ltd., Bombay, India) with water ad libitum at $25 \pm 2{ }^{\circ} \mathrm{C}$ with relative humidity at $50 \pm 15 \%$. The study was approved by the Institutional Animal Ethics Committee of School of Pharmacy, Nalla Narasimha Reddy Education Society's Group of Institutions (003/IAEC/NNRG/2016). Ethical norms were strictly followed during all the experiments.

\section{Nephroprotective activity [11]}

The male rats were divided into 5 groups: Group I served as control group, Group II was disease control received only gentamicin, Group III received standard drug (Vitamin E $250 \mathrm{mg} / \mathrm{kg}$ p.o.) [12], and test groups, i.e., Groups IV and V treated with EEAC at 200 and $400 \mathrm{mg} / \mathrm{kg}$, respectively, orally until 14 days of the study. All the animals except Group I were chronically administered with gentamicin at a dose of $100 \mathrm{mg} / \mathrm{kg}$ body weight i.p. [13]. After the end of the study, the weight of the kidneys was measured, and various parameters were observed in all the groups.

\begin{tabular}{|c|c|c|c|}
\hline S. No. & Group & Treatment & Dose and route \\
\hline 1 & I & Control (vehicle) & Feed and water ad libitum \\
\hline 2 & II & $\begin{array}{l}\text { Disease } \\
\text { control (gentamicin) }\end{array}$ & $100 \mathrm{mg} / \mathrm{kg}$ i.p. \\
\hline 3 & III & $\begin{array}{l}\text { Gentamicin followed } \\
\text { by vitamin E }\end{array}$ & 250 mg/kg p.o. \\
\hline 4 & IV & $\begin{array}{l}\text { Gentamicin followed } \\
\text { by EEAC }\end{array}$ & 200 mg/kg p.o. \\
\hline 5 & $\mathrm{~V}$ & $\begin{array}{l}\text { Gentamicin followed } \\
\text { by EEAC }\end{array}$ & 400 mg/kg p.o. \\
\hline
\end{tabular}

\section{Biochemical studies}

On day 14 of the experiment, the animals were sacrificed by cervical dislocation, and blood samples were collected by carotid bleeding separately into sterilized dry centrifugation tubes and allowed to stand for 30 minutes at $37^{\circ} \mathrm{C}$. The clear serum was separated at $2500 \mathrm{rpm}$ for 10 minutes using micro centrifuge, and the following biochemical investigation was carried out using commercially available test kits (Robonik India Pvt., Ltd.).

\section{Serum creatinine}

Serum creatinine level in serum was estimated using creatinine test kit by kinetic Jaffe's method. Creatinine forms a colored orange red complex in an alkaline picrate solution. The difference absorbance at fixed times during conversion was proportional to the concentration of creatinine in the sample and was studied at $492 \mathrm{~nm}[14,15]$.

Creatinine + Alkaline picrate $\longrightarrow$ Creatinine picrate complex

\section{Total protein}

Total protein level in serum was estimated using total protein test kit according to biuret method, end point. Proteins together with copper ions form a violet blue color complex in alkaline solution. The absorbance of the color was directly proportional to the concentrations and was studied at $540 \mathrm{~nm}[16,17]$

Proteins $+\mathrm{Cu}^{2+} \longrightarrow$ Colored complex

\section{Histopathology of kidneys}

Kidneys of sacrificed animals were identified and carefully dissected out for histopathological studies. After rinsing in normal saline, sections were taken from each harvested kidney. The tissue was fixed in $10 \%$ formal saline, dehydrated with $100 \%$ ethanol solution and embedded in paraffin. It was then processed into $4-5 \mathrm{~m}$ thick sections stained with hematoxylin-eosin and observed under a photomicroscope (magnification power $-\times 40$ ).

\section{Statistical analysis}

GraphPad Prism software, version 5.0 was used in the statistical analysis of experimental data. The statistical analysis was performed using analysis of variance followed by Dunnett's multiple comparison test. $p$ values - $p<0.0001, p<0.01$, and $p<0.05$ were considered as significant.

\section{RESULTS}

Effect of EEAC on body weights and kidney weights against gentamicin-induced animals

Tables 1 and 2 show the effect of EEAC on the body and kidney weights in various groups after inducing of gentamicin. The results were clearly shown that there is the significant increase in body weights in standard and test groups when compared to the disease control group and the other hand, kidney weights also changes by gentamicin induction while recovery was seen by EEAC and vitamin E treatment.

\section{Effect of EEAC on serum creatinine and total protein levels against} gentamicin-induced animals

Tables 3 and 4 show a marked increase in serum creatinine levels in gentamicin treated group compared to control and coadministration of EEAC dose dependently decreased the rise in serum creatinine as like standard vitamin E. A marked increase in total protein concentration was noted in gentamicin treated group compared to control. Coadministration of EEAC and vitamin E decreased the rise in total protein concentration.

\section{Histopathological studies}

The histopathology of Group I rats kidney showing normal tubules and epithelial lining. Whereas, the Group II rats showing dilated tubules and degeneration of epithelial lining. Group III animals showing comparatively similar to normal. Groups IV and V animals showing a reduction in features mentioned in Group II. The results were shown in Fig. 1.

\section{DISCUSSION}

Although the exact incidence of drug-induced nephrotoxicity is not known, it is important for clinicians to be aware of the risks in certain patients and to know which drugs are the most commonly implicated. Nephrotoxicity can be defined as renal disease or dysfunction that arises as direct or indirect result of exposure to medicines and industrial or environmental chemicals [18]. Chronic intraperitoneal administration of rats with $100 \mathrm{mg} / \mathrm{kg}$ gentamicin for causes serious harmful effects and is evident on renal function tests [19]. Thus, it could be suggested that gentamicin must be given in the lowest effective therapeutic doses in patients with normal kidney function. Gentamicin is an antibiotic widely used in treating severe Gram-negative infections. However, its clinical use is limited by its nephrotoxicity. Several lines of evidence indicate that reactive oxygen metabolite or free radicals are important mediators of gentamicin nephrotoxicity [20]. Gentamicin usually accumulates in renal proximal tubules and enhances hydrogen peroxide generation by the mitochondria, which is mostly derived from the dismutation of superoxide [21]. Hydrogen peroxide generated during the gentamicin-induced oxidative stress in mitochondrial membranes releases iron from the mitochondria. The released iron makes a complex with gentamicin and accelerates the oxidative stress [22]. Among the main approaches used to ameliorate or protect the gentamicin-induced nephrotoxicities, the most consistent effects have been observed with the use of antioxidant agents [23]. Some antioxidant agents that have been used to ameliorate gentamicin-induced nephrotoxicity in rats include deferoxamine, methimazole, vitamin E, vitamin C diethyl dithiocarbamate, L-histidinol, thymoquinone [24].

This study aimed to evaluate the protective effect of the A. cepa plant leaves against gentamicin-induced nephrotoxicity in rats. Gentamicin administered rats (toxic control group) had encountered acute kidney dysfunction an evidenced by significant elevation of serum creatinine, total protein and decreased body weight with multiple histological damages. Treatment with the A. серa at the dose level of $200 \mathrm{mg} / \mathrm{kg}$ 
Table 1: Effect of EEAC on body weights against gentamicin-induced animal

\begin{tabular}{lllll}
\hline S. No & Groups & Treatment & Dose & Before treatment (g) \\
\hline 1 & $G_{1}$ & Normal & - & $215.20 \pm 1.23$ \\
2 & $G_{2}$ & Gentamicin+vehicle & $100 \mathrm{mg} / \mathrm{kg}$ & $215.16 \pm 1.28$ \\
3 & $G_{3}$ & Vitamin E & $250 \mathrm{mg} / \mathrm{kg} / \mathrm{p} .0$. & $219.12 \pm 2.86$ \\
4 & $G_{4}$ & EEAC & $200 \mathrm{mg} / \mathrm{kg} \mathrm{p.o.}$ & $226.26 \pm 2.56$ \\
5 & $\mathrm{G}_{5}$ & EEAC & $400 \mathrm{mg} / \mathrm{kg} \mathrm{p.o.}$ & $219.62 \pm 3.12$ \\
\hline
\end{tabular}

Values are expressed as Mean \pm SEM of six animals. Statistical significance test for comparisons was done by one-way ANOVA, followed by "Dunnett's multiple comparison test." Comparisons were done between (a) Group I versus Group II and (b) Group II versus Group III, IV, and V. **p<0.01, ${ }^{* *}$ p $<0.001$. ns: Nonsignificant, SEM: Standard error of mean, EEAC: Ethanolic extract of Allium cepa

Table 2: Effect of EEAC on kidney weights against gentamicin-induced animals

\begin{tabular}{llll}
\hline S. No & Groups & Treatment & Dose \\
\hline 1 & $\mathrm{G}_{1}$ & Normal & - \\
2 & $\mathrm{G}_{2}$ & Gentamicin+vehicle & $100 \mathrm{mg} / \mathrm{kg}$ \\
3 & $\mathrm{G}_{3}$ & Vitamin E & $250 \mathrm{mg} / \mathrm{kg} / \mathrm{p.o.}$ \\
4 & $\mathrm{G}_{4}$ & EEAC & $200 \mathrm{mg} / \mathrm{kg} \mathrm{p.o.}$ \\
5 & $\mathrm{G}_{5}$ & EEAC & $0.825 \pm 0.066$ \\
\hline
\end{tabular}

Values are expressed as Mean \pm SEM of six animals. Statistical significance test for comparisons was done by one-way ANOVA, followed by "Dunnett's multiple comparison test." Comparisons were done between (a) Group I versus Group II and (b) Group II versus Group III, IV, V. ${ }^{*} p<0.05$, ${ }^{* *} p<0.01,{ }^{* * *} p<0.001$. ns: Nonsignificant, SEM: Standard error of the mean, EEAC: Ethanolic extract of Allium cepa

Table 3: Effect of EEAC on serum creatinine levels against gentamicin-induced animals

\begin{tabular}{lllll}
\hline S. No & Groups & Treatment & Dose & Serum creatinine levels (mg/dl) \\
\hline 1 & $G_{1}$ & Normal & - & $1.050 \pm 0.090$ \\
2 & $G_{2}$ & Gentamicin+vehicle & $100 \mathrm{mg} / \mathrm{kg}$ & $5.388 \pm 0.2642^{* * *}$ \\
3 & $G_{3}$ & Vitamin E & $250 \mathrm{mg} / \mathrm{kg} / \mathrm{p} .0$. & $1.798 \pm 0.131^{* * *}$ \\
4 & $\mathrm{G}_{4}$ & EEAC & $200 \mathrm{mg} / \mathrm{kg} \mathrm{p.o.}$ & $4.512 \pm 0.19^{* * *}$ \\
5 & $\mathrm{G}_{5}$ & EEAC & $400 \mathrm{mg} / \mathrm{kg}$ p.o. & $2.475 \pm 0.147^{* * *}$ \\
\hline
\end{tabular}

Values are expressed as Mean \pm SEM of six animals. Statistical significance test for comparisons was done by one-way ANOVA, followed by "Dunnett's multiple comparison test." Comparisons were done between (a) Group I versus Group II and (b) Group II versus Group III, IV, V. ${ }^{* *}$ p $<0.01,{ }^{* * *}$ p $<0.001$. ns: Nonsignificant, SEM: Standard error of the mean, EEAC: Ethanolic extract of Allium cepa

Table 4: Effect of EEAC on total protein concentration against gentamicin-induced animals.

\begin{tabular}{lllll}
\hline S. No & Groups & Treatment & Dose & Total protein concentration (g/dl) \\
\hline 1 & $G_{1}$ & Normal & - & $7.54 \pm 0.32$ \\
2 & $G_{2}$ & Gentamicin + vehicle & $100 \mathrm{mg} / \mathrm{kg}$ & $9.963 \pm 0.65^{* *}$ \\
3 & $G_{3}$ & Vitamin E & $250 \mathrm{mg} / \mathrm{kg}$ p.o. & $7.80 \pm 0.32^{* * *}$ \\
4 & $G_{4}$ & EEAC & $200 \mathrm{mg} / \mathrm{kg} \mathrm{p.o.}$ & $9.267 \pm 0.89^{* *}$ \\
5 & $G_{5}$ & EEAC & $400 \mathrm{mg} / \mathrm{kg} \mathrm{p.o.}$ & $7.360 \pm 0.23^{* * *}$ \\
\hline
\end{tabular}

Values are expressed as mean \pm SEM of six animals. Statistical significance test for comparisons was done by one-way ANOVA, followed by “Dunnett's multiple comparison test." Comparisons were done between (a) Group I versus Group II and (b) Group II versus Group III, IV, V. **p < 0.01, *** $<0.001$. ns: Nonsignificant, SEM: Standard error of the mean, EEAC: Ethanolic extract of Allium cepa

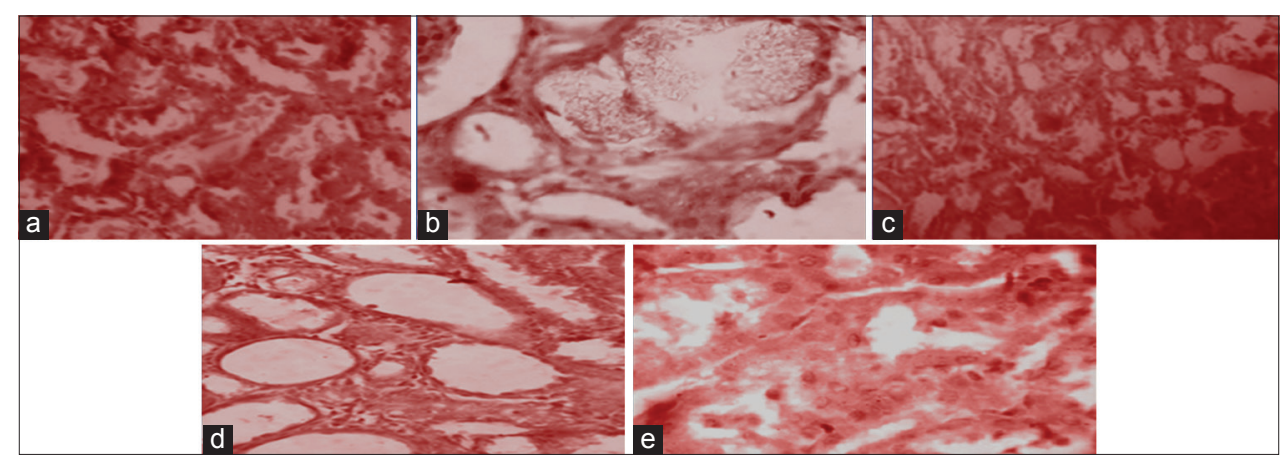

Fig. 1: Histopathological studies (a) Control group, (b) disease control, (c) standard group, (d) ethanolic extract of Allium cepa (EEAC) $200 \mathrm{mg} / \mathrm{kg}$, (e) EEAC $400 \mathrm{mg} / \mathrm{kg}$

body weight and $400 \mathrm{mg} / \mathrm{kg}$ body weight for 14 days significantly lowers the level of serum creatinine, total protein when compared with the toxic group.
The statistical significance of the nephroprotective activity of $A$. серa treated group and potent antioxidant vitamin E treated group (both the groups were compared with toxic control) was found almost equal 
as both groups gained the same level of significance against the toxic group in most of the parameters including serum creatinine, total protein, kidney weights, and body weights. Hence, the review of the study is concluded that the herbal drug possesses nephroprotective activity and it has been proven by different animal models, which gives many links to develop the future trials.

\section{REFERENCES}

1. Porter GA, Bennett W. Nephrotoxic acute renal failure due to common drugs. Am J Physiol 1981;241(7):252-6.

2. Patel S, Ingalhalli R. Role of plants as nephroprotective agents. Int $\mathbf{J}$ Ther Appl 2015;26:6-14.

3. Martínez-Salgado C, Rodríguez-Barbero A, Rodríguez-Puyol D, Pérez de Lema G, López-Novoa JM. Involvement of phospholipase A2 in gentamicin-induced rat mesangial cell activation. Am J Physiol 1997;273:F60-6.

4. Griffiths G, Trueman L, Crowther T, Thomas B, Smith B. Onions - A global benefit to health. Phytother Res 2002;16(7):603-15.

5. Kyoung AL, Kee-Tae K, Hyun JK, Myong-Soo C, Pahn-Shick C, Hoon P, et al. Antioxidant activities of onion (Allium cepa L.) Peel extracts produced by ethanol, hot water, and subcritical water extraction. Food Sci Biotechnol 2014;23(2):615-21.

6. Geeta BK, Kaksha JP, Bhargav MP, Seema NB, Tripathi CB. Evaluation of cardioprotective effect of aqueous extract of Allium cepa Linn. bulb on isoprenaline-induced myocardial injury in Wistar albino rats. Res Pharm Sci 2016;11(5):419-27.

7. Amit K, Kundan SB, Amteshwar SJ, Richa S. Comparative evaluation of neuroprotective effect of three varieties of Allium cepa in chronic constriction injury induced neuropathic pain. Thai J Pharm Sci 2016;40(1):9-20.

8. Gummalla P, Anusha VL, Hemalatha $\mathrm{CH}$, Anil KY, Sravani K. Anxiolytic and anticonvulsant activity of methanolic extract of Allium cepa Linn (onion) bulbs in Swiss albino mice. J Pharmacogn Phytochem 2015;4(2):131-5

9. Ozougwu JC. Anti-diabetic effects of Allium cepa (onions) aqueous extracts on alloxan-induced diabetic Rattus novergicus. J Med Plants Res 2011;5(7):1134-9.

10. Teklit GA. In vitro antimicrobial efficacy of fractions from onion (Allium cepa) leaves extract from Wukro, Ethiopia. Am J Life Sci 2015;3(5):365-8

11. Bibu KJ, Joy AD, Mercey KA. Therapeutic effect of ethanolic extract of Hygrophila spinosa T. Anders on gentamicin-induced nephrotoxicity in rats. Indian J Exp Biol 2010;48(9):911-7.
12. Paoulomi C, Aniruddha M, Subhangkar N. Protective effects of the aqueous leaf extract of Aloe barbadensis on gentamicin and cisplatin-induced nephrotoxic rats. Asian Pac J Trop Biomed 2012;2(3):S1754-63.

13. El-Badwi SM, Bakhiet AO, Abdel EH. Hemato-biochemical effects of aqueous extract of Khaya senegalensis stem bark on gentamicin induced nephrotoxicity in Wistar rats. J Biol Sci 2012;12(6):361-6.

14. Allston CA. In: Anderson SC, Cockayne S, editors. Non Protein Nitrogenous Compounds and Renal Function. Clinical Chemistry: Concepts and Application. Philadelphia, PA, USA: WB Saunders; 1993. p. 369

15. Vasiliades J. Reaction of alkaline sodium picrate with creatinine: I. Kinetics and mechanism of formation of the mono-creatinine picric acid complex. Clin Chem 1976;22(10):1664-71.

16. Christensen SE. In: Anderson SC, Cockayne S, editors. Proteins, Clinical chemistry: Concepts and Application. Philadelphia, PA, USA: WB Saunders; 1983. p. 188.

17. Tiez NW. Clinical Guide to Laboratory Tests. $3^{\text {rd }}$ ed. Philadelphia, PA, USA: WB Saunders; 1995. p. 518.

18. Karra G, Nadendla R, Sindhu B, Umamaheshwera RV. Nephroprotective, nephrocurative activity of Mimosa pudica root against gentamicin induced nephrotoxicity. Int J Pharm Pharm Sci 2015;7(4):173-7.

19. Vijay KK, Naidu MU, Anwar AS, Ratnakar KS. Probocol protects against gentamicin induced nephrotoxicity in rats. Indian $\mathrm{J}$ Pharmacol 2000;32:108-13.

20. Nitha B, Janardhanan KK. Aqueous ethanolic extract of morel mushroom mycelium Morchella esculenta, protects cisplatin and gentamicin induced nephrotoxicity in mice. Food Chem Toxicol 2008;46(9):3193-9.

21. Paoulomi C, Bodhisattawa C, Sudhangkar N. Review on nephroprotective activity study by different plant extract. Adv J Pharm Life Sci Res 2014;2(2):24-40.

22. Afeefa T, Uzma S, Saeed M, Furqan KH, Khalid H, Nadeem IB, et al. Evaluation of protective and curative role of $\alpha$-lipoic acid and selenium in gentamicin induced nephrotoxicity in rabbits. Pak J Pharm Sci 2012;25:103-10.

23. Konda VR, Madhavi E, Lakshmipathy PR, Maignana KR. Antioxidant and nephroprotective activities of Aconitum heterophyllum root in glycerol induced acute renal failure in rats. J Clin Diagn Res 2016;10(3):FF01-5.

24. Faouzi D, Salah A, Mohamed RD, Zine K. Effect of the joint supplementation of vitamin $\mathrm{C}$ and vitamin $\mathrm{E}$ on nickel heamatotoxicity and nephrotoxicity in male swiss albino mice. Int $\mathrm{J}$ Pharm and Pharm Sci 2016;8(6):234-9. 